\title{
Uma nova sensibilidade nas práticas de saúde
}

\author{
A new sensibility in healthcare practices
}

Monica de Assis ${ }^{1}$

Muitas mudanças têm marcado a política de saúde brasileira nos últimos vinte anos, porém a redefinição das práticas neste campo permanece sendo uma urgente necessidade. De modo sintético e ao mesmo tempo denso, Eymard ocupa-se desta questão vital no seu texto, explicitando o potencial da Educação Popular nessa construção.

Enfocar este tema inclui pensar como as relações interpessoais nos serviços de saúde devem ser cuidadas para que não reproduzam dominação, mas germinem formas mais solidárias e democráticas de viver e lutar coletivamente por melhor saúde e qualidade de vida. Poucos olhares, de fato, voltam-se a esta dimensão interativa entre profissionais de saúde e população, apesar da centralidade de sua problematização para o projeto da Saúde Coletiva.

Do ponto de vista da minha experiência com práticas educativas e interdisciplinares no nível assistencial, reforçaria a relevância do que Eymard denomina de prática de saúde alargada. A complexidade da saúde exige realmente inovações que superem a assepsia técnica e propiciem a interação com a dinâmica popular, visando à busca de alternativas e soluções, individuais e coletivas, para os problemas apresentados. Há inúmeras dificuldades para este tipo de investimento e que devem ser amplamente discutidas e enfrentadas. Entretanto, é este um norte valioso no sentido de inquietar e evitar acomodações aos agudos limites da prática institucional.

Sobre o diálogo e seu papel na diminuição do fosso cultural entre técnicos e população, destacaria que, como via de mão dupla, além de compreender e explicitar o saber do interlocutor popular, implica facilitar a socialização e o debate do saber técnico que orienta as ações de saúde. O reforço da capacitação e autonomia das pessoas requer continuado empenho em tornar acessível a racionalidade técnica e organizativa dos serviços, para que possa ser, tanto quanto possível, entendida e abertamente questionada. Há um papel importante do profissional aí, melhor cumprido quanto mais permitir a livre expressão do outro e do "universo de resistência" (Ayres, 2000), e mais pautado for numa permanente autocrítica dos avanços e limites da ciência.

\footnotetext{
1 Núcleo de Atenção ao Idoso, Universidade Aberta da Terceira Idade, Universidade do Estado do Rio de Janeiro. <monassis@terra.com.br>
} 
Algo mais fecunda o diálogo como possibilidade de encontro e afirmação de sujeitos. O conhecimento sozinho não opera desejos. Para transformar realidades, diz Rubem Alves (1996), é preciso amor, elemento que move o educador em seu ofício de criar mundos. Em sua visão: "Mundos a serem criados, antes de existirem como realidade, existem como fantasias de amor."

Esta é uma das sintonias que estabeleço com a idéia de que a Educação Popular em Saúde não é uma atividade a mais, mas uma nova postura que reordena a globalidade do serviço. Não é possível, de fato, apre(e)nder, ser parceiro, inventar mundos, lutar juntos, prescindindo da amorosidade. "Educar exige querer bem", lembrava Paulo Freire (1998). Aí temos um diferencial, não suficiente mas necessário, em relação à desatenção para com o elemento humano, até hoje uma expressiva marca das práticas na área da saúde.

Acrescentaria a importância de ampliação e legitimação de uma atividade a mais: os grupos educativos. Não por serem originais ou virtuosos em si mesmos. Mas pela oportunidade singular de recolocar a questão saúde no espaço coletivo, aprofundar aprendizados, fortalecer vínculos, propor abordagens lúdicas, dimensões ainda pouco valorizadas no contexto assistencial.

A opção, no texto, da expressão construção histórica de uma medicina integral (p.126) leva-me a uma interrogação. Embora ela denote sentido amplo, não seria estratégico deslocar o foco do saber médico para realçar a dimensão interdisciplinar do objeto saúde? Esta idéia, aliás, é incorporada pelo autor ao propor nova harmonia na equipe de saúde, fundada no reconhecimento das limitações profissionais diante dos aspectos sociais $e$ políticos do adoecimento humano.

Tais limitações têm sido destacadas na discussão atual da Promoção da Saúde enquanto um novo paradigma das políticas de saúde em nível mundial. Embora este campo conceitual resulte da confluência de forças distintas e mobilize vigorosa polêmica filosófica e política, por exemplo, sobre o que vem a ser o bem estar humano, penso que a interface com o movimento de Educação Popular em Saúde é organicamente necessária. Até mesmo para que seu reconhecido elemento inovador e pioneiro seja preservado e fortalecido neste tempo de idéias globais.

\section{Referências bibliográficas}

ALVES, R. Concerto para corpo e alma. Campinas/SP: Papirus/Speculum, 1998.

AYRES, J. R. C. M. Sujeito, intersubjetividade e prevenção: um ensaio filosófico.In:CONGRESSO BRASILEIRO DE SAÚDE COLETIVA, 6, 2000, Salvador. Anais... Salvador, 2000 (cd-rom).

FREIRE, P. Pedagogia da Autonomia. Saberes necessários à prática educativa. 7 ed. São Paulo: Paz e Terra, 1998.

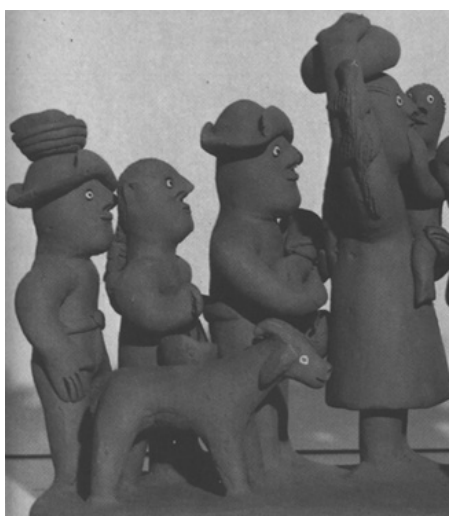

